Firat University Journal of Experimental and
Computational Engineering

\title{
Effect of layer number on bending behavior of 3D spacer composite plates produced with different methods
}

\author{
Farklı yöntemlerle üretilen 3B boşluklu kompozit plakaların tabaka sayısının eğilme \\ davranısıına etkisi
}

\author{
Serkan ERDEM ${ }^{1 * \text { iD }}$, Mete Onur KAMAN² (D), Mustafa GÜR ${ }^{3}$ iD \\ 1,2,3 Department of Mechanical Engineering, Engineering Faculty, Firat University, Elazig, Turkey. \\ ${ }^{1}$ serdem@ firat.edu.tr, ${ }^{2}$ mkaman@ firat.edu.tr, ${ }^{3}$ mgur@ firat.edu.tr
}

\begin{abstract}
In this study, the three-point bending behavior of laminated composite plates reinforced with three-dimensional (3D) spacer fabric was experimentally investigated. Composite plate production was carried out using hand lay-up and vacuum infusion (VARI) method. Three-point bending test results of composite plates produced as a single layer were experimentally compared. Afterwards, composite plates with 2 and 3 layers were obtained by vacuum infusion method and load displacement graphs were obtained by subjecting them to three-point bending test. There was no significant difference between the load carrying capacities of the single-layer composite plates produced by hand lay-up and vacuum infusion method in the three-point bending test. According to the three-point bending test, the maximum load obtained $105 \mathrm{~N}$ in hand lay-up production is $8 \%$ greater than the vacuum infusion method. While the maximum load was $602 \mathrm{~N}$ in the plate produced in the 2-layer vacuum infusion method, it was obtained as $923 \mathrm{~N}$ in the 3-layer.
\end{abstract}

Keywords: 3D spacer composites, Three-point bending, Glass fiber, Vacuum infusion, Failure load.

\section{Özet}

Bu çalışmada, üç boyutlu (3B) boşluklu kumaş ile güçlendirilmiş tabakalı lamine kompozit plakların üç nokta eğilme davranışı deneysel olarak incelenmiştir. Kompozit plak üretimi elle yatırma ve vakum infüzyon yöntemi kullanılarak gerçekleştirilmiştir. Tek tabakalı olarak üretilen kompozit plakların Üç nokta eğilme test sonuçları deneysel olarak karşılaştırılmıştır. Sonrasında vakum infüzyon yöntemiyle 2 ve 3 tabakalı olarak kompozit plak elde edilmiş ve bunlar üç nokta eğilme testine tabi tutularak yük yer değiştirme grafikleri elde edilmiştir. Elle ve vakum infüzyon yöntemiyle üretilen tek tabakalı kompozit plakların üç nokta eğilme testinde yük taşıma kapasiteleri arasında kayda değer bir fark bulunmamıştır. Üç nokta eğme testine göre elle yatırmalı üretimde $105 \mathrm{~N}$ elde edilen maksimum yük, vakumlu infüzyon yöntemine göre \%8 daha fazladır. 2 katmanlı vakum infüzyon yönteminde üretilen plakada maksimum yük $602 \mathrm{~N}$ iken, 3 katmanlıda $923 \mathrm{~N}$ olarak elde edilmiştir.

Anahtar kelimeler: 3 boyutlu boşluklu kompozitler, Üç nokta eğilme, Cam fiber, Vakum infüzyon, Hasar yükü.

\section{Introduction}

In order to increase the strength of the materials used in the construction, their thickness should be increased. However, doing this causes the weight of the materials to increase. The increase in weight causes an increase in energy costs in cases such as the production or transportation of materials. This situation contributes not only economically but also to global warming. Therefore, increasing the strength without increasing the thickness necessitates the addition of core material between the materials. The materials created in this type are called sandwich materials. Anything desired can be used as core material. Sandwich structure can be obtained by placing core material between composite materials. However, in these cases, there may be adhesion problems between the composite and the core material. Spacer fabrics are 3D sandwich fabric which are fabric at the bottom and top and fiber as the core.

${ }^{*}$ Corresponding author 
Considering this advantage of spacer fabrics, many studies have been carried out. When the studies are examined: Green et al. calculated stress-strain under tensile loading for a 3D woven composite using the voxel method and damage analysis in finite element analysis. The aim of the study is to compare the idealized geometry with the real geometry by simulation. Simulated geometry models produced results close to experiments [1]. Neje et al. have produced woven spacer fabrics with different cell geometries such as rectangular, trapezoidal and triangular. Sandwich composite plates were produced from these fabrics by vacuum infusion method. The produced sandwich composites were analyzed for their quasi-static lateral compression and bending performances [2]. Safari et al. have created new hybrid composites by filling the channels of porous composites with polymer nanocomposite. Natural zeolite/polyurethane was used as nanocomposite. Flat compression, edge compression, three-point bending and weight drop tests were applied to measure the mechanical response of the samples. It has been obtained that zeolite particles significantly improves the mechanical properties of the filled composite sandwich panels [3]. Sadighi et al. investigated the mechanical behavior of 3D woven glass fiber sandwich composites experimentally and by the finite element method. Flat directional pressure, edge directional pressure, shear and three-point bending tests were performed for three different core thicknesses of sandwich panels. Consistency was obtained in the experimental studies with the studies carried out with the finite element method [4]. Zhang et al. investigated the effect of surface layer structure on 3D woven spacer composites. The effect of flat and complex surface layer on 3D woven spacer composites was investigated by three-point bending, quasi-static compression and low-speed impact tests [5]. Li et al have produced 3D spacer woven composites with thickened face layers. The effect of thickened surface layers was investigated by static compression and impact tests. Tests have shown that the face layer is an important parameter. The thickened face layers significantly improved the warp compression and impact properties [6]. Li et al. produced composites with thickened surface layers with 3D spacer woven fabric with the VARI process. Three-point bending test and fracture mechanism were analyzed to evaluate the effect of the thickened surface plates. It has been reported that the surface plate thickness is a parameter that affects the mechanical properties of the 3D spacer woven composite [7]. Umair et al. produced composites by hand lay-up technique using 3D spacer woven E-glass fabric with three thickness levels $(4,10$ and $20 \mathrm{~mm})$ as fiber and epoxy resin as matrix. The stiffness of the fabric increased as the sample thickness increased, and the bending modulus decreased as the length of the 3D spacer woven fabrics increased. As the sample thickness increased, the bending and slow velocity impact strength of the 3D spacer woven composites decreased [8]. Wang et al. produced composites using 3D spacer glass woven fabric as fiber and epoxy resin as matrix. The produced composites exhibited excellent compressive strength as well as good thermal insulation [9]. Atar et al. [10] evaluated the effect of core geometry on bending stiffness and transverse shear stiffness in corrugated core sandwich panels experimentally and numerically. Threedimensional composite sandwich panels with rectangular, trapezoidal and triangular cross-section geometries were produced. A significant relationship was found between the direction of corrugation and the load carrying capacity.

When the studies in the literature are examined, it is seen that the composite plates are produced only by hand lay-up or VARI technique [1-10] and the produced plates are obtained as a single 3D spacer layer. Unlike the literature in this study, the effect of these two production techniques on bending strength was investigated experimentally. In addition, multi-layer composite plate was produced with the VARI method, and the effect of the increase in the number of layers on the increase in bending behavior was investigated. Obtained strength behavior for three-point bending test were presented in graphic form.

\section{Material and Method}

In this study, composite plates were produced using 3D spacer glass fiber fabrics (Figure 1). Composite plate production was carried out by hand lay-up and VARI method. While 3D spacer glass fabric was used as fiber, F-1564 resin and F3487 hardener set purchased from Fibermak Composites Izmir, Turkey were used as matrix. The mixing ratio of resin and hardener is 100:34 respectively. $800 \mathrm{~g}$ matrix and $1 \mathrm{~m}^{2}$ fabric were used.

\subsection{Hand lay-up method}

The spacer glass fiber fabric was laid on the bench floor and the resin, hardener mixture was applied to the fabric manually with the help of a roller. The fabric was left to dry for 24 hours at room temperature. Then, the test samples were cut from the composite plate in accordance with ASTM D790 [11] standards by marble cutting machine. 


\subsection{VARI method}

Each step of the VARI production steps was applied sequentially [12-13]. The production is based on the principle that the resin is given on the one hand and the fabric is wetted on the other hand. In vacuum infusion; The resin is given to the system under the effect of vacuum and left to wait under the same vacuum. Sandwich structure cannot be obtained because the lower and upper face sheets of 3D spacer fabrics will stick together due to vacuum and the wall thickness of the obtained composite plates will decrease. However, in this study, primarily a sandwich structure was desired, so resin was injected into the system and the entire fabric was wetted (Figure 2a).

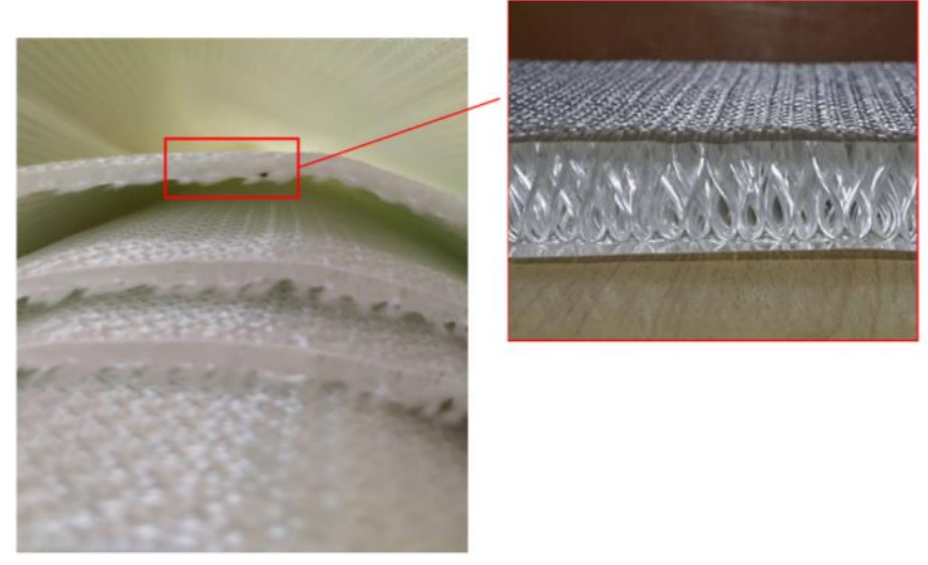

Figure 1. 3D spacer glass fabrics used for composite plate production

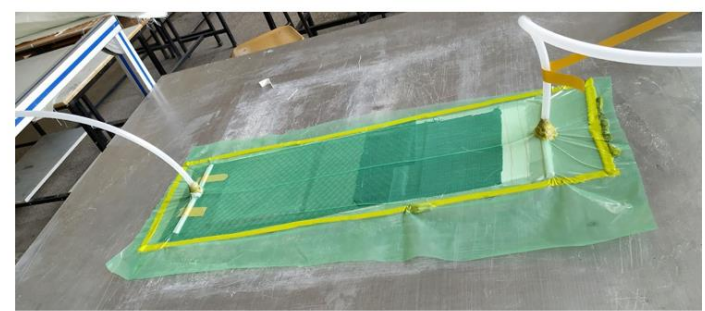

a)
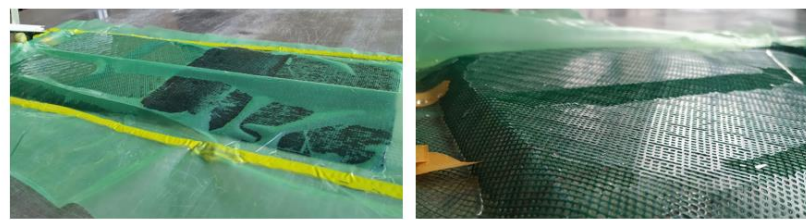

b)

Figure 2. Production of composite plates using VARI method a) the vacuum applying, b) removing the vacuum and drying

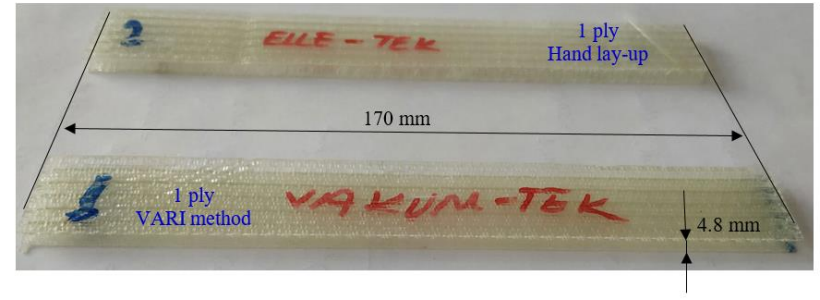

Figure 3. Thicknesses of one layer specimens produced with hand lay-up and VARI method 
Then, the vacuum was removed and the fabrics were stretched to rise back and formed a sandwich structure (Figure $2 b$ ). In vacuum infusion production, the vacuum was turned off when the process of giving resin to the fabric was finished. This time is approximately two minutes. At the end of the vacuum process, the fabric has become 3D by itself. The thickness of the composite plates produced as a single layer was obtained as $4.8 \mathrm{~mm}$ in both methods. Experiment samples were obtained from the produced composite plates according to ASTM D790 standards by using marble cutting machine (Figure 3). In the production of multi-layer composites, dry fabrics were placed on top of each other and then the vacuum infusion production steps explained above were repeated. Resin-impregnated fabrics were cut into desired dimensions after waiting for 24 hours at room temperature. After fabrication, the total thicknesses of the 2- and 3-layer composite plates were measured as $9.2 \mathrm{~mm}$ and $13.6 \mathrm{~mm}$, respectively. Three-point bending tests were carried out one week after production.

\subsection{Three-point bending test}

Three-point bending test of 3D composite plates produced by hand lay-up and vacuum infusion method and cut in ASTM D790 standard was performed at $0.5 \mathrm{~mm} / \mathrm{min}$ speed on Utest $10 \mathrm{kN}$ tensile device (Figure 4). The dimensions of all specimens are $25 \times 170 \mathrm{~mm}$. The thicknesses are $4.8 \mathrm{~mm}$ (Figure 3).



Figure 4. Universal tension test machine and three-point bending test setup

\section{Results and Discussions}

Load displacement graphs were obtained from the three-point bending test results of composite plates produced from 3D spacer glass fiber fabric by hand lay-up and vacuum infusion method. In addition, the maximum bending strength was also determined.

\subsection{Hand lay-up method}

Three-point bending result graph of the composite plate produced as a single layer from 3D spacer glass fiber is shown in Figure 5. In Figure 5, the maximum load of $108.61 \mathrm{~N}$ and a displacement of $0.463 \mathrm{~mm}$ were obtained in the loaddisplacement graph. It has been observed that the relationship between load and displacement is linear. This indicates that the material behaves brittle. After the maximum load, there was a sudden drop in load.

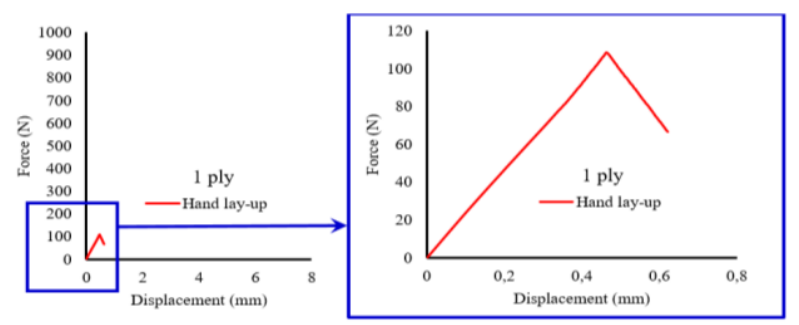

Figure 5. Force-displacement graph of one-layer composite sandwich produced with hand lay-up 


\subsection{VARI method}

The load-displacement behaviors of composite plates produced from 3D spacer glass fiber fabric as single, double and triple layers were obtained as shown in Figure 6. The load-displacement behavior of the composite plate produced with VARI method as a single layer is linear [14]. This behavior is similar to that of plates produced by the hand lay-up method. The bending behavior of two- and three-layer composites is non-linear, unlike single-layer composites. Depending on the manufacture, the height of each layer may not be the same. For this reason, the resistance of each layer to bending will be slightly different. Therefore, partial deviations from linearity are seen in the graphs up to the maximum load. However, sudden but partial decreases in load are seen in the graph of multi-layer composites. During bending, shear stresses will arise between the layers. This will force the matrix holding the layers together to suffer damage. Therefore, regional delamination damage may occur between layers. Karahan et al. stated that damages occurred on foam-filled 3D spacer composite samples as extra skin-core delamination [15]. Another damage behavior is regional core crushing on the load applied surfaces. Since the load-displacement behavior is linear in monolayer composites, such damage also determines the bending stiffness of the plate. However, in multi-layer composites, the first layer is crushed first at the load contact point $[8,16-17]$. Then the second layer is broken. In the triple layer, fracture occurs in the last layer. This causes a gradual decrease in the load.

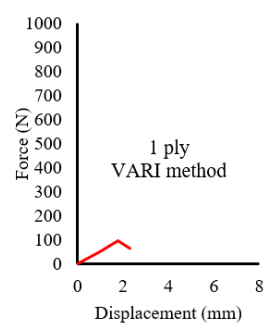

a)

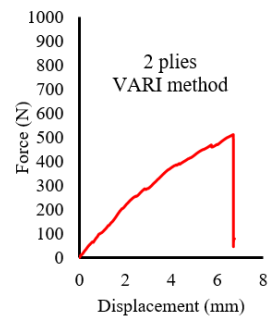

b)

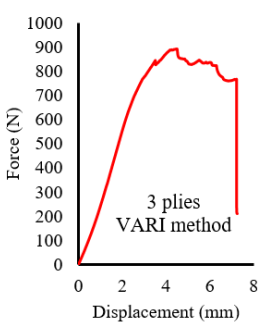

c)

Figure 6. Force displacement graph of composite plate consisted of a) one ply, b) two plies and c) three plies

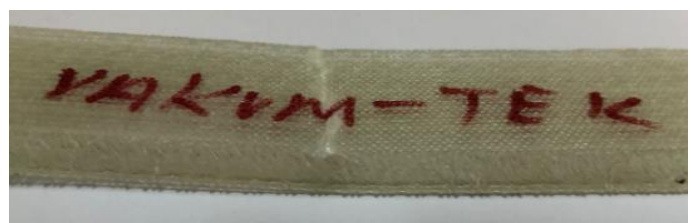

a)

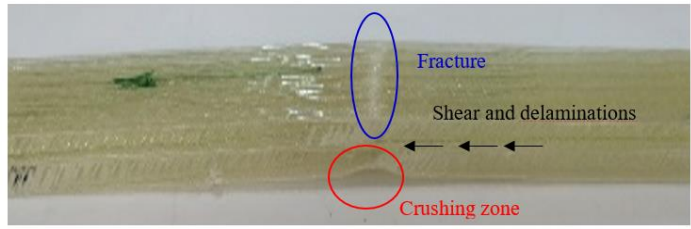

b)

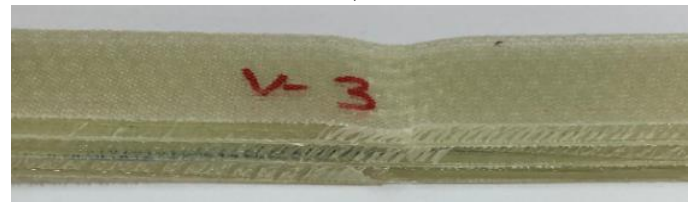

c)

Figure 7. Failure mechanisms of composite plate consisted a) one, b) two and c) three plies

Maximum damage loads of single-layer composite plates produced by hand lay-up and vacuum infusion method and twoand three-layer composite plates produced by vacuum infusion method are presented in Figure 8. According to the threepoint bending chart, the maximum load obtained $105 \mathrm{~N}$ in hand lay-up production is $8 \%$ greater than the vacuum infusion 
method. Manufacturing the composite plate by hand lay-up or by vacuum infusion method had limited effect in terms of maximum load. While the maximum load was $602 \mathrm{~N}$ in the plate produced in the 2-layer vacuum infusion method, it was obtained as $923 \mathrm{~N}$ in the 3-layer.

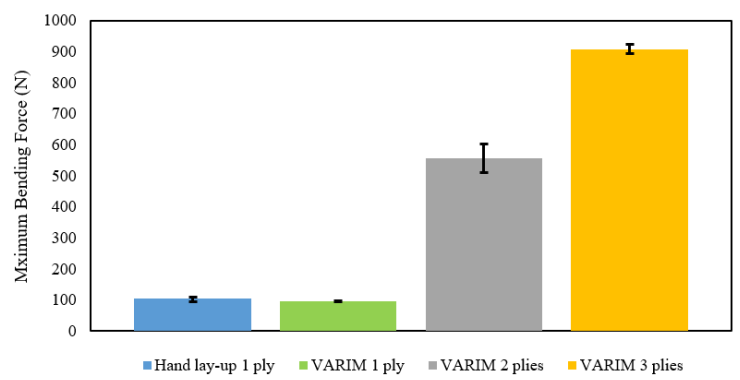

Figure 8. Variation of maximum bending forces with layer number and production method

\section{Conclusion}

In this study, 3D spacer glass fiber reinforced composite plates were produced using hand lay-up and VARI method. The results obtained as a result of the three-point bending test can be summarized as follows.

- Different production methods used for monolayer composites changed the bending stiffness by $8 \%$. This shows that the production method does not have a significant effect on the bending stiffness.

- The increase in the number of layers increased the bending load. A strength increase of $\sim 600 \%$ was obtained when two layers were used, and $\sim 900 \%$ when three layers were used.

- The bending behavior of the monolayer composite is linear. However, the bending behavior of two- and three-layer composites is non-linear. In addition, partial load drops have occurred due to sheet crushing and delamination at the load contact point.

\section{Author Contribution Statement}

In the study, Author 1 contributed making the design and literature review; Author 2 contributed to forming the idea, the analysis of the results, provision of the materials and examination of the results; Author 3 contributed to checking the spelling and checking the article in terms of content.

\section{Ethics Committee Approval and Conflict of Interest}

There is no need for an ethics committee approval in the prepared article. There is no conflict of interest with any person/institution in the prepared article.

\section{References}

[1] Green SD, Matveev MY, Long AC, Hallett SR. "Mechanical modelling of 3D woven composites considering realistic unit cell geometry". Composite Structures, 118, 284-293, 2014.

[2] Neje G, Behera BK. "Investigation of mechanical performance of 3D woven spacer sandwich composites with different cell geometries". Composites Part B, 160, 306-314, 2019.

[3] Safari H, Karevan M, Nahvi H. "Mechanical characterization of natural nano-structured zeolite/polyurethane filled 3D woven glass fiber composite sandwich panels". Polymer Testing, 67, 284-294, 2018.

[4] Sadighi M, Hosseini SA. "Finite element simulation and experimental study on mechanical behavior of 3D woven glass fiber composite sandwich panels". Composites: Part B, 55, 158-166, 2013.

[5]Zhang M, Wang X, Liu S, Li F, Wu G. "Effects of Face Sheet Structure on Mechanical Properties of 3D Integrated Woven Spacer Composites”. Fibers and Polymers, 21(7), 1594-1604, 2020. 
[6] Li DS, Jiang N, Jiang L, Zhao CQ. "Static and dynamic mechanical behavior of 3D integrated woven spacer composites with thickened face sheets". Fibers and Polymers, 17(3), 460-468, 2016.

[7] Li DS, Zhao CQ, Jiang N, Jiang L. "Fabrication, properties and failure of 3D integrated woven spacer composites with thickened face sheets". Materials Letters, 148, 103-105, 2015.

[8] Umair M, Hamdani STA, Nawab Y, Asghar MA, Hussain T, Saouab A. "Effect of Pile Height on the Mechanical Properties of 3D Woven Spacer Composites". Fibers and Polymers, 20(6), 1258-1265, 2019.

[9] Wang L, Zhang K, Farha FI, Ma H, Qiu Y, Xu F. "Compressive strength and thermal insulation properties of the 3D woven spacer composites with connected spacer yarn structure". Journal of Materials Science, 55(6), 2380 $2388,2020$.

[10] Atar HA, Zarrebini M, Hasani H, Rezaeepazhand J. "The effect of core geometry on flexural stiffness and transverse shear rigidity of weight-wise identical corrugated core sandwich panels reinforced with 3D flat spacer knitted fabric". Polymer Composites, 41(9), 3638-3648, 2020.

[11] Masoumi M, Mansoori H, Dastan T, Sheikhzadeh M. "An experimental investigation into flexural properties of hybrid carbon-basalt triaxially braided composite lamina". Composite Structures, 284, 115231, 2022

[12] Erdem S, Gur M, Kaman MO. "Nonlinear buckling behavior of hybrid composites with different notch types". Materials Testing, 63(9), 797-804, 2021.

[13] Erdem S, Gur M, Kaman MO. "Effect of patch dimension and fiber orientation on non-linear buckling of hybrid composites". Materials Testing, 63(10), 929-942, 2021.

[14] Li M, Wang S, Zhang Z, Wu B. "Effect of structure on the mechanical behaviors of three-dimensional spacer fabric composites". Applied Composite Materials, 16(1), 1-14, 2009.

[15] Karahan M, Gul H, Karahan N, Ivens J. "Static behavior of three-dimensional Integrated core sandwich composites subjected to three-point bending". Journal of Reinforced Plastics and Composites, 32(9), 664-678, 2013.

[16] Hassanzadeh S, Hasani H, Zarrebini M. "Mechanical characterization of innovative 3D multi-cell thermoset composites produced with weft-knitted spacer fabrics". Composite Structures, 184, 935-949, 2018.

[17] Hamedi S, Hasani H, Dibajian SH. "Numerical simulating the flexural properties of 3D weft-knitted spacer fabric reinforced composites". Journal of composite materials, 51(13), 1887-1899, 2017. 